\title{
Frikoppling, sammankoppling och besvärliga maktrelationer $i$ socialt arbete
}

\section{LEILI LAANEMETS, TINA MATTSSON \& VANNA NORDLING}

\author{
Syftet $i$ denna artikel är att med fokus på kön och etnicitet \\ undersöka och problematisera kategorianvändning i prak- \\ tiskt socialt arbete. Utgångspunkt tas $i$ den kritiska teori- \\ traditionen $i$ socialt arbete, som betonar relationen mellan \\ strukturell nivå och individnivå.
}

\section{Inledning}

Jag kanske kan ta ett exempel, det är en, vad är han, 50-åring var han kanske, frän $X$-land [namn på icke-skandinaviskt land], som har bott $i$ Sverige $i$ många år, men han är inte svensk medborgare, han är lite kriminell. Nu, nu vet jag inte om jag gjorde rätt när jag sa X-land, jag kanske utpekar... (...) ta inte med det ordet, X-land, för det kan ju påverka alla X-ländare, alltså någon tänker att de är sådana...

Leili Laanemets, fil dr och lektor i socialt arbete, Socialhögskolan, Lunds universitet.

Tina Mattsson, fil dr och lektor i socialt arbete, Socialhögskolan, Lunds universitet.

Vanna Nordling, doktorand i socialt arbete, Socialhögskolan, Lunds universitet.
Socialarbetarens funderingar i citatet speglar det sociala arbetets komplexitet och svårigheten att prata om och definiera kategorier. Som socialarbetare måste man på olika sätt förhålla sig till klienter man möter, något man gör genom att på olika sätt kategorisera dem. Socialarbetaren ovan är medveten om att hennes sätt att beskriva klienter kan bidra till stigmatisering, och hon visar stor försiktighet och tveksamhet i vilka ord hon använder när hon pratar om sin klient. Citatet präglas av osäkerhet och rädsla för att göra fel. En lösning blir att tala om ålder och kriminalitet, men även medborgarskap utifrån indelningen svensk och icke svensk, kategoriseringar som tycks uppfattas som mindre problematiska, än att tala om en specifik nationalitet eller 
etnisk tillhörighet. Vad är det som gör att vi ibland känner en rädsla för att säga och göra "fel" när vi använder oss av olika kategorier? Varför är vissa kategorier känsligare än andra? Finns det ett "rätt" sätt att använda kategorier?

I föreliggande artikel vill vi med fokus på kön och etnicitet undersöka och problematisera kategorianvändning i socialt arbete. Artikeln bygger på empiriskt material från två olika kvalitativa studier, en som belyser arbetet med våld i nära relationer och en som undersöker hur kategorin etnicitet används och förstås inom beroendebehandling. I våra diskussioner om studierna upptäckte vi att det fanns paralleller i materialen i förhållande till hur socialarbetarna resonerade kring och brottades med kategoriseringar och samhällsrelaterade maktstrukturer (Mattsson 2011; Nordling 2011). ^ ena sidan använde de ofta kategoriseringar för att synliggöra bland annat olika klientgruppers utsatthet, ojämlikhet, resultat av socialt arbete, lärande och kunskapsproduktion. $\AA$ andra sidan var de samtidigt ofta försiktiga och tveksamma inför hur och när de talade om kön och etnicitet eftersom de visste att de riskerade att bidra till reproduktion och stereotypifiering när de kategoriserade sina klienter. Vissa kategoriseringar var också oladdade medan andra var påtagligt laddade, vilket gjorde dem särskilt svåra att prata om och använda. De svårigheter och utmaningar som socialarbetarna gav uttryck för känner vi igen i vår egen praktik som forskare och lärare, där även vi tvingas balansera i förhållande till hur, när och på vilket sätt vi använder och talar med hjälp av kategoriseringar. Vi vill undersöka dessa svårighe- ter och utmaningar närmare och presenterar begreppen sammankopplande och frikopplande. Begreppen har vuxit fram genom en analys av de empiriska materialen, där vi försökt förstå de svårigheter och utmaningar som vi såg att socialarbetarna brottades med i de båda studierna. Med begreppet frikopplande avser vi ett förhållningsätt där socialarbetare skiljer strukturella mönster från den egna praktiken på individnivå. Med sammankopplande vill vi fånga hur socialarbetare kan pendla mellan en strukturell maktförståelse och individnivå. Vår utgångspunkt är att de utmaningar som kategoriseringar aktualiserar, är angelägna att uppmärksamma för såväl praktiskt socialt arbete som utbildning och forskning. Det krävs alltid en balansgång mellan att å ena sidan använda kategorier för att kunna tala och synliggöra, men där det å andra sidan samtidigt finns en risk att osynliggöra och återskapa de maktrelationer som ligger till grund för dem.

\section{Kategorier, samhällsstrukturer och överordning}

Socialt arbete är rikt på kategoriseringar i såväl praktiskt arbete, utrednings- och utvecklingsarbete som forskning. Vissa kategoriseringar är mer laddade än andra och kategorier som är omdebatterade eller uppfattas som politiserade kan vara svåra att hantera i det vardagliga arbetet. Socialt arbete sker inte i ett vacuum utan samverkar med det omgivande samhället, med dess system av över- och underordning där grupper av människor kategoriseras på basis av exempelvis kön, etnicitet, sexu- 
alitet och klass, vilket också innebär en risk att bidra till förtryck och diskriminering (Brookfield 2009; Dominelli 2004; Fook 2002; Mattsson 2005, 2010; Sakamoto \& Pitner 2005).

För att kunna förstå detta har vi sökt våra teoretiska utgångspunkter i feministisk postkolonial teori och den kritiska teoribildningen i socialt arbete. Detta innebär att vi utgår från ett maktperspektiv. Vi förstår kategorier som föränderliga och kontextbundna och som skapade genom sociala, politiska, ekonomiska och historiska processer (Anthias \& Yuval-Davis 1996; Börjesson \& Palmblad 2008; Dominelli 2002; Essed 1991; Fook 2002; de los Reyes \& Mulinari 2005). Etnicitet och kön är centrala kategorier $\mathrm{i}$ analysen och vår utgångspunkt innebär att de förstås som dimensioner av sociala relationer som kontinuerligt konstrueras och reproduceras. Föreställningar relaterade till kropp, kultur, språk, nationell bakgrund, religion etc. samverkar på olika sätt $\mathrm{i}$ konstruktionen av etnicitet och kön (Fenstermaker \& West 2002; de los Reyes \& Mulinari 2005). Kön, sexualitet, klass och etnicitet är grundläggande för hur resurser och makt fördelas och är därmed också särskilt centrala för hur vi kategoriserar och begripliggör människor (Dominelli 2002; Mattsson 2010). Därutöver har i studier om etnicitet, begreppet rasialisering förts in som ett sätt att benämna föreställningar knutna till egenskaper som tillskrivs individer utifrån "ras" och "invandrarskap" (de los Reyes 2007).

Tilly (2000) är intresserad av ojämlikhet i organisationer. Han menar att alla organisationer använder sig av det han kallar inre (interna) kategorier i förhållande till sitt verksamhetsområde för att organisera och strukturera arbetet. För socialt arbete är sådana grundläggande inre kategorier exempelvis missbrukare, fattig, barn och vuxen men också uppdelningen mellan klient och socialarbetare. Yttre (externa) kategorier förs in i organisationen utifrån. Vi kommer använda Tillys resonemang för att förstå hur kategorierna kön respektive etnicitet verkar inom organisationer, med fokus på hur de enskilda socialarbetarna diskuterar kring sitt arbete. Vi tänker oss att den överordnande position som socialarbetare intar i förhållande till klienten påverkas av yttre kategorier, som kön, sexualitet, klass och etnicitet. Dessa yttre kategorier är både sammanlänkande med och resultatet av samhälleliga maktstrukturer som över- och underordnar människor och grupper till varandra, de förs mer eller mindre medvetet in i det sociala arbetet (Brookfield 2009; Fook 1993, 2002; Fook \& Gardner 2007; Mattsson 2010; Mclaughlin 2005; Morley 2004; Pitner \& Sakamoto 2005; Sakamoto \& Pitner 2005; Stepney 2005). Mattsson (2005) har exempelvis påvisat hur kön, klass och sexualitet är centrala för att åtskillnad mellan klient och socialarbetare skall kunna göras och upprätthållas. För praktiker i socialt arbete är det viktigt att vara medveten om dessa maktrelationer och hur det intrikata samspelet av olika över- och underordningar påverkar både dem själva och deras arbete. En central fråga för ett kritiskt socialt arbete blir hur man hanterar den egna positionen i förhållande till klienten.

Ahmed (2004) har brottats med frågan om överordningens privilegier och pekar på svårigheten att förstå och utmana privi- 
legierade positioner. Hon tar utgångspunkt i ett ökande intresse för och uppmärksamhet kring vithet, ett intresse som återfinns bland annat inom forskning men också inom anti-rasistiska rörelser. Att tala om vithet och sin privilegierade position blir dock ofta, menar Ahmed, ett sätt att befria sig från ansvaret och den skuld som positionen rymmer. Muntliga deklarationer där man, närmast rutinmässigt, erkänner sin skuld och sin överordning används i själva verket för att fly undan ansvaret för de konsekvenser överordningen får för underordnade grupper. Erkännandet blir ett enkelt sätt att vara "god", till intet förpliktigande (jfr Pease 2010). Vad Ahmed pekar på är den svårighet och smärta som ligger i insikten av att vara överordnad och privilegierad och att denna position alltid sker på andras bekostnad. Hon ger ingen enkel lösning på hur det är möjligt att ta ansvar men man kan tolka henne som att det handlar om att stanna i de känslor av smärta och skuld som väcks:

...race, like sex, is sticky; it sticks to us, or we become 'us' as an effect of how it sticks, even when we think we are beyond it. Beginning to live with that stickiness, to think it, feel it, do it, is about creating a space to deal with the effects of racism (Ahmed 2004, s. 49)

Ahmeds resonemang är användbara för att förstå viljan men också svårigheten att synliggöra och hantera maktrelationer i socialt arbete. Det är något som måste sättas ord på, talas om och försöka förstås, först då kan en förändring av maktrelationer ske.

En viktig teoretisk förståelse $i$ vårt arbete är att intention och medvetenhet inte är nödvändiga villkor för att upprätthålla exempelvis sexism, rasialisering eller homofobi. Young (2002) uttrycker det tvärt om som att förtryck återskapas och upprätthålls till följd av: "... ofta omedvetna föreställningar och beteendemönster bland vanliga, hyggliga medmänniskor [vår kursiv] i vardagliga möten, i medier och kulturella stereotyper, i kontakt med byråkratiska strukturer och hierarkier och på de olika 'marknaderna"' (Young 2002, s. 54; även Essed 1991, s. 45). Denna utgångspunkt möjliggör en förståelse av hur den enskilda individen riskerar att reproducera ojämlika relationer och bidra till diskriminering och förtryck oavsett goda intentioner om motsatsen. I vår förståelse är vi alla aktörer i ett samhälle som präglas av maktstrukturer som skapar över- och underordning i relation till kön, sexualitet, klass och etnicitet. Att utmana de omedvetna föreställningar som detta skapar hos oss är möjligt, men kräver medvetandegöranden om desamma - och det är just om dessa medvetandegöranden som denna artikel handlar.

\section{Vårt arbetssätt och de studerade verksamheterna}

Analysen i artikeln är ett resultat av ett gemensamt arbete utifrån två olika empiriska material som båda aktualiserar hur socialarbetare förhåller sig till kategoriseringar och maktstrukturer. Båda studierna är kvalitativa i sina utgångspunkter. Den första är genomförd vid en enhet som arbetar med våld i nära relationer och dess syfte var att undersöka de metoder och arbetssätt som användes vid enheten, och

Laanemets, Mattsson \& Nordling: Frikoppling, sammankoppling och besvärliga... 
att belysa vilka utmaningar detta arbete stod inför. Arbetet följdes genom deltagande observationer och intervjuer, både individuella och i grupp, med personalen (Mattsson 2011, 2014). Den andra studien syftade till att synliggöra hur personal inom missbruksvården tillmätte etnicitet en betydelse för deras arbete. Ett trettiotal personer anställda inom den sociala och medicinska missbruksvården intervjuades om och på vilket vis etnicitet hade en påverkan i arbetet med klienterna (Nordling 2011). När vi utbytte erfarenheter från våra respektive studier insåg vi att vi oberoende av varandra hade funderat över hur socialarbetare på olika sätt förhöll sig till och hanterade maktstrukturer och kategoriseringar. Vi blev intresserade av att undersöka detta närmare och försöka förstå vad de empiriska materialen sa om maktstrukturer och kategoriseringar i socialt arbete. Respektive studie var då redan avslutad och nu påbörjade vi ett nytt gemensamt analytiskt arbete av våra olika material. Detta har gjorts $i$ olika steg. Utifrån vår gemensamma diskussion läste först var och en genom sitt material och sökte systematiskt efter hur socialarbetarna förhöll sig till maktstrukturer och kategoriseringar. Denna läsning resulterade i en rad citat och exempel som hela gruppen tog del av och som vi sedan gemensamt analyserade. Vi diskuterade de mönster vi såg i materialen och försökte förstå hur och när socialarbetarna i de båda studierna brottades på liknande men också på olika sätt (Robson 2004; Silverman 1995). Vi arbetade med en medvetenhet om att de båda studierna inte är fullt jämförbara, då de hade olika syften och baserades delvis på olika metodologiska angreppssätt. I analysen av materialen framkom dock två återkommande förhållningssätt som vi valt att benämna frikopplande respektive sammankopplande.

Studiernas olikheter innebar både möjligheter och svårigheter. I studien av arbetet med våld i nära relationer var kön en central kategorisering som socialarbetarna använde sig av och som aktualiserades genom deras praktik. I studien om beroendevården var det i första hand missbruk som var praktikens kategoriseringsinstrument medan etnicitet var en kategorisering som studien aktualiserade, och som visade sig aktualiseras på olika sätt i de praktiska verksamheterna. Detta innebar att studierna gav exempel på likheter men också variationer i vilka maktrelationer som var svåra att hantera och vilka som var lättare. I studien om arbetet med våld i nära relationer var det empiriska materialet dessutom mer dynamiskt eftersom observationer utförts, det gjorde att denna studie gav möjligheter att förstå hur de utmaningar som socialarbetarna ställdes inför hanterades i praktiken, något som saknades i det andra materialet. Dessa olikheter har inneburit begränsningar. Omläsningen av materialet och vårt gemensamma arbete har många gånger pekat på intressanta aspekter, exempelvis hur personal av olika kön tycks förhålla sig till könsstrukturer. Detta har vi dock inte kunnat fördjupa oss i eftersom materialet från de båda studierna i sin grund är olika och inte fullt ut bär för den komparation en sådan analys skulle kräva. Vår bedömning är dock att materialet räcker till för den analys vi gör, där vi riktar fokus mot hur socialarbetare hanterar och förstår 
kategoriseringar och maktstrukturer i socialt arbete. Studiernas olikheter är både en styrka och svaghet i förhållande till våra föreslagna begrepp. Det är en styrka att samma mönster återfinns i två olika studier vilket tyder på att begreppen är relevanta. Studiernas olikheter är samtidigt en svaghet eftersom det innebär begränsade möjligheter att på ett systematiskt vis undersöka begreppen i sig.

I våra omläsningar av materialet har vi provat olika förståelser utifrån teorier om samhällstrukturer, makt, kategorisering och ojämlikhet och begreppen frikopplande respektive sammankopplande blev ett sätt att förstå olika förhållningssätt till maktstrukturer. Vi kunde se hur de intervjuade, ofta under en och samma intervju skiftade mellan dessa två, ibland intogs ett förhållningssätt där de såg sig som opåverkade av maktstrukturer medan de andra gånger menade sig vara påverkade av dessa. Det är viktigt att påpeka att förhållningssätten inte var fixerade eller kopplade till enskilda individer, även om vi kunde se att vissa intervjupersoner tenderade att använda det ena eller det andra förhållningssättet mer frekvent. Förhållningsätten skall alltså inte förstås som statiska, utan bör tolkas som något de intervjuade går in i och ut ur, beroende på om och när de uppfattar kategorier som svåra och laddade, eller begripliga och användbara. De citat och iakttagelser som lyfts fram från studierna skall även förstås som utvalda exempel som illustrerar mönster vi sett i de båda materialen.

Innan vi övergår till analysen följer en kort presentation av de verksamheter som ingått i de studier vi baserar oss på och ett förtydligande kring vilka kategoriseringar som aktualiserades inom dessa verksamheter

\section{Studie 1: Våld i nära relationer}

Den första studien är genomförd av Mattsson (2011) och inkluderar deltagande observationer om sammanlagt en månads tid samt åtta individuella och fyra gruppintervjuer med personal vid en socialtjänstbaserad enhet som arbetar med våld i nära relationer.

I arbetet med våld i nära relationer har kategorierna offer och förövare länge varit grundläggande. Dessa har knutits på ett tydligt sätt till kön i den bemärkelsen att man talat om mäns våld mot kvinnor och oftast organiserat separerade verksamheter för å ena sidan kvinnor som utsatts för mäns våld och å andra sidan för män som utsatt kvinnor för våld. Vid den enhet som stod i fokus i den aktuella studien är dessa kategorier, offer - förövare samt män och kvinnor centrala för verksamheten, men inte på samma sätt som de ofta varit i denna form av arbete. Utgångspunkten för arbetet är att kvinnor och män inte nödvändigtvis innebär de tydligt åtskiljda klientgrupperna: kvinnor som utsatts för mäns våld och män som utövar våld mot kvin nor. Enheten tar emot både kvinnor och män och arbetar med dem både separerat (i individuella samtal och i gruppverksamheter) och tillsammans (i exempelvis par- och familjebehandling). En viktig utgångspunkt är att den som utövat våld inte sällan har erfarenhet av att själv ha utsatts för våld (exempelvis som barn) och den som utsatts

Laanemets, Mattsson \& Nordling: Frikoppling, sammankoppling och besvärliga... 
för våld också kan ha utövat våld (exempelvis som försvar i våldsrelationen eller mot sina barn). Denna utgångspunkt innebär att kvinnor och män inte entydigt kan skiljas åt i offer- respektive förövarposition. Kategorierna kvinnor, män, offer, förövare glider därför samman och vävs in i varandra. Samtidigt som denna överlappning finns mellan hur kvinnor och män förstås i förhållande till kategorierna offer och förövare, organiseras verksamheten på ett tydligt sätt $\mathrm{i}$ förhållande till kön. I gruppverksamheterna arbetar man till exempel med en kvinnogrupp för kvinnor som utsatts för våld och en mansgrupp som riktar sig till män som utövar våld och som kan ha erfarenheter av att själva ha utsatts för våld.

\section{Studie 2: Missbruksvård och etnicitet}

Den andra studien är genomförd av Nordling (2011) och omfattar 25 intervjuer med 31 anställda inom socialtjänst och beroendevård, med tonvikt inom socialtjänsten. För de verksamheter som ingår i studien om missbruks- och beroendevård är kategorin missbrukare den absolut mest centrala för förståelsen av den klientgrupp man arbetar med. Detta är en lätt identifierbar kategori, även om den inkluderar alkohol-, narkotika- och spelmissbruk. Det sker dock en differentieringsprocess, till exempel uppmärksammas kön, olika former av missbruk och olika psykiatriska diagnoser, både i det sociala arbetets organisering och i det praktiska arbetet med klienter. Ibland aktualiseras etnicitet som en möjlig ytterligare grund för kategorisering i arbetet, till exempel finns behandlingshem som vänder sig särskilt till vissa etniska grupper.

Syftet med studien var att undersöka hur och när etnicitet användes som kategorisering i arbetet med missbruk. I studien lämnades stort utrymme för intervjupersonerna att själva definiera och ta upp frågor som de ansåg kunde kopplas till etnicitet, då ingen av verksamheterna som representerades använde etnicitet som en specifik eller uttalad kategori för arbetet. Det är alltså informanternas erfarenheter av hur etnicitet aktualiseras och när det är relevant i deras arbete som studien representerar. Etnicitet kan förstås och ges varierande innebörd och aktualiserades också på olika sätt $\mathrm{i}$ intervjuerna. I flera intervjuer associerade till exempel informanterna etnicitet med erfarenhet av att migrera och att personer som har upplevt krig i ursprungslandet har erfarenheter som skiljer sig från personer som växt upp i Sverige. Etnicitet förknippades även med diskriminering och att vissa etniska grupper har sämre förutsättningar i samhället. Etnicitet förknippades med olikhet $i$ kultur, exempelvis när det gäller synen på och användningen av vissa droger. Vissa informanter uttryckte att det fanns ett stort behov av att kategorisera utifrån etnicitet medan andra tyckte att sådana kategoriseringar var fullständigt överflödiga. Många intervjupersoner rörde sig också mellan dessa olika ståndpunkter under en och samma intervju.

\section{Att frikoppla praktiken från samhällsstrukturen}

I båda studierna fanns ett flertal situatio- 
ner där socialarbetarna visade tveksamhet inför vad de yttre kategorierna kön och etnicitet innebar och hur de skulle kunna användas i arbetet, något som ibland ledde till att de intog ett frikopplande förhållningsätt. Detta resulterade i att socialarbetarna gjorde en åtskillnad mellan den egna praktiken och samhälleliga strukturer. De ansåg att yttre kategorier kunde vara relevanta för att förstå samhället på en strukturell nivå men att kategorier inom verksamhetens ramar, i mötet med klienten, var mer komplexa och mångfacetterade. Flera intervjupersoner tycktes mena att de inte ville peka ut, definiera eller skapa stereotypa kategoriseringar. Samtidigt som denna försiktighet kan vara positiv ser vi också exempel där maktstrukturer riskerar att osynliggöras. Förhållningssättet kombinerades ibland med införandet och användandet av andra kategoriseringar, exempelvis genom att prata om hur klienterna inte kunde svenska, inte var svenska medborgare eller inte kände till hur det svenska systemet fungerade. Därigenom skapades nya kategorier där etniska aspekter var både närvarande och frånvarande. De nya beskrivningarna användes dock som om de var mindre laddade och mer objektiva eller neutrala än att definiera klienters etniska bakgrund. Märkbart var att dessa nya kategoriseringar byggde på negationer, ett ickegörande, där klienterna definierades i förhållande till vad de inte var i förhållande till språk, medborgarskap och/eller kunskaper om det svenska systemet. Denna neutralisering menar vi riskerar att skapa de klienter med invandrarbakgrund som socialarbetarna uppfattar som annorlunda på grund av hudfärg, religion och/eller kultur, som en icke-kategori där de görs till negationer i förhållande till "det svenska".

Vid enheten som arbetade med våld i nära relationer pratade socialarbetarna om män och kvinnor som förhållandevis enhetliga och självklara kategorier. Kvinnor och män, offer och förövare och deras erfarenhet av våld var centrala och grundläggande kategoriseringar för verksamheten men våld förstods samtidigt som ett komplext fenomen som inte kunde förstås genom dessa uppdelningar. Några intervjupersoner gav med hänvisning till komplexitet ett tydligt uttryck för motstånd mot förståelser som kopplade våld i nära relationer till samhällets könsstrukturer. De sa att förklaringar som synliggör och problematiserar mäns våld mot kvinnor innebar alltför förenklade kategoriella förståelser av män som förövare och kvinnor som offer. En av intervjupersonerna förklarade att strukturella och feministiska perspektiv var ett problem för arbetet eftersom de: gör en person till förövare och en till offer. Och så ser det inte ut för min del... Intervjupersonen framhöll att i det arbete som han utförde gick det inte att arbeta med de enhetliga och uppdelade könsrelaterade kategorier som en strukturell förståelse skapade. Möjligheten att män kunde erfara våld och att kvinnor kunde utöva våld gjorde det mycket problematiskt att överhuvudtaget använda strukturella förståelser av våld i nära relationer framhöll intervjupersonen. Både han och hans kollegor gjorde en form av frikopplande som handlade om att särskilja den verksamhet de arbetade inom från det övriga samhället. De påtalade komplexiteten i enskilda ärenden och klientmöten och sa att denna gjorde att strukturella mönster var mycket 
svåra att skönja i deras vardagliga praktik. Maktstrukturer var något som eventuellt fanns i samhället utanför och på strukturell nivå, men inom ramen för den verksamhet där de själva arbetade och i de möten de hade med klienter, fanns inte dessa. Flera intervjupersoner i studien av missbruksvård gjorde frikopplingar när de pratade om maktstrukturer och etnicitet. A ena sidan tillskrev flera intervjupersoner maktstrukturer en betydelse, å andra sidan placerade de ofta denna betydelse utanför den egna verksamheten och praktiken. Att etnicitet är sammanlänkat med maktrelationer, diskriminering och förtryck, var något flera intervjupersoner gav uttryck för, men de tycktes mena att denna form av maktrelationer i första hand var aktuellt för andra och i andra sammanhang. Till exempel kunde de tala om rasism bland klienterna, något som de som behandlare behövde sätta gränser för. Det egna terapeutiska rummet ansågs vara fritt från rasialiserande föreställningar. En av intervjupersonerna sa till exempel att:

...det är klart att [skillnader utifrån etnicitet] finns där $i$ ett samhällsperspektiv men utifrån hur vi arbetar så ser det ju annorlunda ut.

När intervjupersonerna pratade om sina möten med klienter från olika etniska minoritetsgrupper påtalade de ofta att individen och den individuella relationen var i centrum, något som gjorde etnisk tillhörighet obetydligt för relationen. Några av de intervjuade beskrev att eftersom deras utgångspunkt för verksamheten var just att behandla alla klienter lika, var inte klienternas etniska bakgrund något som påverkade bemötande, bedömningar eller behandlingsinsatser. De hävdade att även om klienternas möjligheter i det svenska samhället påverkades av fördomar om deras etniska tillhörighet/bakgrund/hudfärg, så fanns inte sådana föreställningar och fördomar inom verksamheten eller i den egna praktiken.

Detta sätt att förstå den egna praktiken och socialt arbete som befriat från fördomsfulla och ensidiga kategoriseringar förekom i båda studierna. Intervjupersonerna tenderade att utgå från att deras yrkesroll och de metoder som de använde gav dem förmågan att se bortom kategorier. Med hjälp av sin yrkesroll kunde de frikoppla sig själva från samhällets maktstrukturer. En av de intervjuade i studien av missbruksvård sa:

\section{Eftersom vi jobbar med myndighetsutövning} ska man bemöta alla människor likadant, och lägger man in en massa kulturella värderingar då bemöter man ju inte alla på samma sätt.

En av familjeterapeuterna vid enheten som arbetar med våld i nära relationer framhöll på ett liknande sätt sin terapeutiska kompetens och berättade att han som terapeut förmådde se individen utan att låta sig påverkas av olika kategoriserande föreställningar om kvinnor och män, offer och förövare:

För mig är varje möte ett nytt möte och jag försöker att gå in utan schabloner och att se möjligheten till våld från alla möjliga synvinklar. Och jag tror att vi måste göra upp med frägan om vem som är skyldig här. Jag 
försöker gå in i ett rum utan att ha ett behov av att hitta en skyldigperson.

Genom att inta terapeutiska förhållningssätt och en behandlarroll tycktes intervjupersonerna mena att de befriades från föreställningar om kvinnor och män i våldsrelationer och olika etniska minoriteter, och de betonade att de mötte människorna utifrån vilka de verkligen var. Utgångspunkten för resonemangen var att eftersom arbetssätten helt enkelt krävde att den enskilda individen sattes i centrum och bemöttes objektivt och neutralt - var detta också något man som behandlare inom de olika verksamheterna per automatik lyckades med.

Vid enheten som arbetar med våld i nära relationer ingick ett flertal observationer av verksamheten, vilket fick till följd att bilden av en yrkesroll, fri från de egna föreställningarna och baserad på individuella möten, komplicerades. Som nämnts ovan fanns hos personalen ett kritiskt förhållningssätt mot vad de beskrev som en traditionell förståelse av mäns våld mot kvinnor och man ville arbeta med en mer komplex förståelse av människor och våldsrelationer. Samtidigt fanns en ambition att både se och synliggöra män och mäns erfarenheter av att utöva våld och att själva vara offer för våld. Det visade sig att kombinationen av att arbeta med komplexa tolkningar, och att särskilt synliggöra mäns våldserfarenheter som offer, innebar att personalen hade svårt att samtidigt synliggöra och hantera den våldsrelation som ändå var mest förekommande, vilket var den där kvinnor utsatts för mäns våld. Vid ett tillfälle valde exempelvis en av medarbetarna att frångå Enhetens arbetsrutiner om att alltid göra riskbe- dömningar av våldet och att alltid försäkra sig om att båda parter gavs utrymme att beskriva sin upplevelse av relationen och av våldet. Genom att lyssna framför allt på mannens berättelse gjordes bedömningen att mannen och kvinnan ville fortsätta leva tillsammans och att de skulle få hjälp genom parsamtal, detta trots att det tidigare framkommit att kvinnan var mycket rädd för mannen och ville skiljas, samt att hon tystades i hans sällskap. Med intentionen att utmana stereotypa föreställningar om mäns våld mot kvinnor, blev det svårt för personalen att förmå synliggöra kvinnors utsatthet och mäns överordning i våldsrelationerna, två aspekter som båda är relaterade till maktordningen mellan kvinnor och män. När personalen ville ta avstånd från en strukturell förståelse som de uppfattade blev alltför ensidigt kategoriserande av mäns våldsutövning och kvinnors underordning, hamnade de istället i ett osynliggörande av kvinnors utsatthet och mäns våld, detta trots att huvuddelen av de ärenden som de arbetade med bestod av våldsrelationer där kvinnor och barn var utsatta för mäns våld (Mattsson 2011, 2014).

Sammanfattningsvis kunde vi $\mathrm{i}$ vårt material se hur socialarbetarna använde sig av en rad olika strategier och handlingssätt som resulterade i en frikoppling från kategorier och de maktstrukturer som det sociala arbetets praktik kan förstås som sammanlänkade med och bärare av. De särskilde sin egen position och sitt eget arbete från konsekvenserna av strukturella mönster genom att placera maktrelationer som är tydliga på strukturell nivå, till just och enbart strukturell nivå eller genom att förlägga dem på individnivå men då som ett

Laanemets, Mattsson \& Nordling: Frikoppling, sammankoppling och besvärliga... 
problem hos klienterna. Socialarbetarna såg sin yrkesroll och sitt förhållningssätt som en garant för att de själva inte påverkades eller var en del av maktstrukturer utan de individuella klientmötena ägde rum "utanför" samhället inbäddade i neutralitet. En konsekvens av detta var att de därmed också hade svårt att hantera maktstrukturer när dessa aktualiserades $i$ arbetet.

\section{Sammankoppling mellan praktik och samhällstruktur}

Parallellt med tveksamheterna mot att länka samman strukturellt relaterade maktrelationer med den egna verksamheten och socialarbetarpositionen, fanns andra förhållningssätt till kategorier och maktstrukturer. Dessa består av resonemang där socialarbetarna använder olika former av kategoriförståelser för att fånga både den individnära praktikens komplexitet och betydelsen av strukturella maktrelationer. Vi benämner detta som sammankopplande, då det vilar på att det görs samband som kopplar samman det egna arbetet och verksamheten med strukturella nivåer.

Vid enheten för våld i nära relationer fanns jämsides med motståndet mot strukturella förklaringar ett balanserande förhållningssätt. En del av intervjupersonerna både underströk att strukturella förklaringar är problematiska - och var alltså en del av den starka kritiken mot dessa - men de tycktes samtidigt mena att det för verksamheten fanns en styrka och en användbarhet i strukturella förklaringar av våld. En av dem betonade exempelvis att även om hon såg samhället som ett patriarkat, menade hon inte att alla män utövar våld eller att kvinnor inte kan utöva våld:

Jag definierar vårt samhälle som ett patriarkat, det gör jag, och att kvinnor är mer utsatta $i$ många olika situationer /.../. Men det är ju på generell nivå, varje enskilt fall är ju naturligtvis inte så. Kvinnor utövar också våld /.../ Det är ett fåtal män som använder sig av våld och då talar vi om, om mycket mer fysiskt vaild. I.../ Kvinnorna och barnen är ofta de som varit utsatta på något sätt och männen är de som utsatt...

Detta sätt att sammankoppla en strukturell nivå som synliggör och accepterar omfattningen av mäns våld mot kvinnor och som i en bemärkelse använder enhetliga kategorier när kvinnor förstås som utsatta för mäns våld, med den komplexitet som visar sig i det konkreta/lokala arbetet innehåller flera aspekter. Sammankopplingen ger utrymme både för den strukturella ordningen och för noterande av en avvikelse från den, dvs. att också kvinnor kan slå och män kan vara offer. Lyhördheten för kvinnors och mäns våldsutövning kombinerades med förståelsen av innebörden av maktrelationen mellan kvinnor och män och mäns mer omfattande våld mot kvinnor, vilket gjorde att de intervjuade behöll en medvetenhet om och öppenhet för kvinnors utsatthet. När socialarbetarna intog denna balanserande position kunde de se mäns våldsutövning och mäns utsatthet, utan att tappa bort kvinnors berättelser, erfarenheter och behov.

En central grund för förmågan att sammankoppla var att dessa socialarbetare höll 
fast vid en förståelse om att också de påverkades av maktstrukturer, de såg inte verksamheten eller sig själva som frikopplade från samhället i övrigt. Yrkesrollen i sig sågs inte som en garanti för objektivitet eller förmågan att vara neutral på det sätt som var återkommande för de socialarbetare som frikopplade sig själva från maktstrukturer. Istället framhölls att det fanns en svårighet $i$ arbetet och som krävde en vaksamhet och ett ständigt arbete, nämligen att också de som socialarbetare och terapeuter kunde bli indragna i ett osynliggörande som ofta är en del av den maktordning som kringgärdar våldet. De utgick ifrån att de, precis som alla andra, var en del av strukturella mönster som överordnar män och underordnar kvinnor, och som gör det svårt att se mäns våld (jfr Eduards 2002). Medvetenheten om vad maktstrukturer innebär och hur dessa påverkar relationen mellan kvinnor och män i allmänhet och i arbetet med våld $i$ synnerhet, gav därmed socialarbetarna en viktig sensitivitet i förhållande till den egna positionen. Medvetenheten gjorde att de kontinuerligt arbetade med frågan om hur våldet påverkade dem eller vad det riskerade att göra med dem. De stannade i det obehag som våldet och insikten om att kunna bli en del av det förde med sig. Socialarbetarna uppmärksammade varandra på att inta olika perspektiv i arbetet för att inte exkludera förståelser och erfarenheter och de höll fast vid arbetsmetoder och rutiner som hjälpte dem att inte osynliggöra kvinnor i viljan att uppmärksamma män.

I studien av missbruksvård finns flera exempel på hur intervjupersonerna på liknande sätt iakttog och såg problematiska enhetliga kategoriseringar i sitt arbete och hur de utifrån detta började utmana dem med hjälp av en strukturell förståelse. Ett sätt som detta tog sig uttryck var när personalen på olika sätt reflekterade kring hur kategorier riskerar att blir fastlåsande och förenklande stereotyper.

Det kan vara så att om det är bara svenskar och man pratar om klienterna, såkan det ju bli så att man pratar om invandrare som om det vore liksom en viss slags människa eller något.

Citatet illustrerar hur intervjupersonen funderar kring hur förhållanden på den egna arbetsplatsen och personalens sammansättning bidrar till vad kategorier som "invandrare" kan fyllas med. Några av socialarbetarna reflekterade också över sin egen etnicitet och hur deras egna upplevelser av "svenskhet" eller "invandrarskap" kunde tänkas påverka arbetet. Kategorierna betraktas alltså inte som objektiva och neutrala utan som produkter av lokala situationer och kontexter, vilket i sin tur kan öppna upp för en medvetenhet "underifrån" och "inifrån" om hur sociala och strukturella faktorer påverkar kategoriseringar som exempelvis vi och de Andra. Det får också återverkningar i hur arbetet med klienter organiseras:

...när man har med sig det $i$ sin tolkning att det har med en speciell folkgrupp att göra sà kanske man inte ställer riktigt de frågorna som man behöver ställa, som man hade gjort i vanliga fall.

I citatet ovan konkretiserar socialarbetaren

Laanemets, Mattsson \& Nordling: Frikoppling, sammankoppling och besvärliga... 
de risker som en oreflekterad kategorisering utifrån etnicitet kan innebära. Medvetenheten om hur socialarbetaren själv, med sina förföreställningar, kan bidra till både hur det sociala arbetet utformas och vilka konsekvenser det får, menar vi är en början på funderingar om hur olikhet och uppdelningar skapar förståelser av vi och de Andra.

Andra gånger ledde resonemangen till sammankopplingar som blev grunden för en praktik där socialarbetarna istället kunde tänka utanför de föreställningar de bar med sig, och därmed hitta andra förståelseramar och nya sätt att arbeta. Exempelvis berättade en av de intervjuade behandlarna om hur hon börjat fundera kring en förhållandevis vanlig föreställning om att det är svårt att möta och arbeta med klienter som är i behov av tolk, en föreställning som också förekom i flera andra intervjuer i studien. Intervjupersonen började fundera kring om det egentligen var så omöjligt att arbeta med tolk och började arbeta annorlunda:

[Då] pratade jag om det lite innan [med tolken], att jag önskade att hon försökte översätta så ordagrant som möjligt. Och det fungerade ju, det fungerade ganska bra... Jag tänker att man kan göra ett gott arbete med en tolk. Men man fär kanske räkna med att, jag försöker nog vara lite mer, alltså nästan övertydlig kanske.

Intervjupersonens berättelse visar hur hon börjar ifrågasätta den förenklade kategoriseringen: att arbeta med utgångspunkt i olika språk och med hjälp av tolk är proble- matiskt, och hur hon utifrån sitt ifrågasättande skapade lösningar som både möjliggjorde och utvecklade arbetet. På liknande sätt berättade andra intervjupersoner om hur de ibland gått utanför de inarbetade ramarna för behandlingsarbetet och hittat nya arbetssätt och möjligheter genom att lyssna på och försöka förstå klienten och dennes behov. En utredare berättade exempelvis om hur hon valt att frångå verksamhetens vanliga arbetssätt och tillgodosett en klients önskemål om behandling i utlandet. Genom att socialtjänsten betalade resa och uppehälle kunde klienten genomgå en behandling hon/han själv trodde kunde fungera. Att på detta sätt vara lyhörd och våga utmana och se bortom organisationen kan ses som ett exempel på sammankopplande arbete där klientens situation förstås i ett socialt sammanhang.

I studien av enheten som arbetade med våld i nära relationer blev det tydligt att det var de som intog det sammankopplande förhållningssättet som förmådde att uppmärksamma arbetsgruppen både på "glidningar" $i$ arbetet och analys av hur dessa hade gått till. Glidningarna kunde bland annat bestå av att man i sin fokusering på männen tappade bort och därmed osynliggjorde kvinnornas berättelser av utsatthet och upplevelser av våld. Ett exempel var den incident som nämndes ovan, då en medarbetare frångått arbetsrutinerna vad gällde riskbedömning. Utifrån denna händelse tvingade de i personalen som kopplade samman strukturnivå med individnivå fram en diskussion och en problematisering kring hur kvinnan osynliggjorts när mannens berättelse var den som fått dominera tolkningen av ärendet. 
Sammanfattningsvis menar vi med sammankoppling de strategier som socialarbetare använde sig av när de på olika vis kopplade samman det som gjordes i det konkreta arbetet med en strukturell förståelse. Med denna bas förstod de den egna verksamheten och mötet med klienter genom att länka samman den konkreta praktikens komplexitet med en förståelse av strukturella mönster och där kategorierna förstods som mer enhetliga. När de sammankopplade de båda nivåerna förmådde socialarbetarna också att förhålla sig till en komplexitet som omfattar både individ och strukturnivå och deras yrkesroll. Denna utgångspunkt hjälper dem att bryta med förgivettaganden som begränsar både verksamheten och förståelsen av klienten och på olika sätt problematisera den egna förståelsen av klienter och deras problem.

\section{Slutdiskussion}

Socialt arbete är inbäddat i maktstrukturer som skapar spänningar. Vi har i artikeln presenterat två begrepp för att utforska hur socialarbetare förhåller sig till maktstrukturer och kategoriseringar. Det ena benämner vi frikoppling, det innebär ett handlande och tänkande där individen, arbetet och verksamheten särskiljs från strukturen. Det andra benämner vi sammankoppling, det innebär att socialarbetarna pendlar mellan strukturella maktförståelser och individnivåns komplexitet. När socialarbetarna intar frikopplande förhållningssätt beskriver de sig ofta som objektiva, som om de och verksamheterna de ingår i står utanför och opåverkade av samhällets maktstrukturer och kategoriseringar. När socialarbetarna frikopplar sig och verksamheterna de arbetar inom från övriga samhället avpolitiseras både inre och yttre kategorier på ett sätt som kan innebära en risk för att reproducera maktordningar och den ojämlikhet som kategorierna är sammanlänkade med. I sammankopplande förhållningssätt är socialarbetarna därmed medvetna om sin egen position och roll i en samhällskontext. De ser både sig själva och andra som delaktiga i och upprätthållare av maktstrukturer. Samhällskontexten vävs med andra ord in i förståelsen av den egna praktiken och verksamheten. Detta innebär att det finns en potential för att synliggöra och utmana maktrelationer.

Strukturella förklaringar säger oss något väsentligt om det vi möter i det sociala arbetets vardagspraktik - och vi menar att det krävs ett sammankopplande mellan den vardagliga komplexiteten och de mer stelbenta strukturerna för att vi skall kunna begripliggöra vardagsverkligheten. Strukturella perspektiv innebär förståelser som begripliggör samhällsgrupper och kategorier på ett enhetliggörande sätt, medan praktiken på individnivå ofta är betydligt med komplex och dynamisk. För att få ihop dessa nivåer krävs ett pendlande reflektionsarbete; en förmåga att både gå nära det enskilda fallet och se dess unika drag, och att backa och se det på distans för att förstå hur det också kan ha att göra med samhällstrukturer som påverkar oss. Närheten ger möjlighet att gå in i och undersöka den komplexitet som socialarbetaren möter i det enskilda ärendet och mötet med klienten, medan distansen innebär att backa från denna komplexitet och sätta

Laanemets, Mattsson \& Nordling: Frikoppling, sammankoppling och besvärliga... 
den i relation till större samhällsrelaterade sammanhang. Genom att länka samman de människor och de sociala problem som socialarbetare möter i det praktiska arbetet, med en förståelse för människors olika levnadsvillkor, blir det möjligt att hålla fast vid och synliggöra maktordningar och ojämlikhet som annars tenderar att vara svår att ta tag $\mathrm{i}$, blotta och ta ansvar för. Det sammankopplande förhållningssättet är med denna utgångspunkt användbart och eftersträvansvärt $i$ socialt arbete för att pendla mellan närhet och distans och se hur både inre och yttre kategorier påverkar arbetet.

Kategoriseringar som synliggör makt och ojämlikhet på strukturell nivå är inte alltid lika enkla att hantera på individnivå. Pease (2010) understryker hur svårt det är för oss att acceptera vår egen överordning och ta ansvar för den, hur vi gärna vill fly undan och rusa in i mindre laddade områden, exempelvis egna upplevelser av just underordning. Frågan om mäns våld mot kvinnor är laddad och att det är särskilt svårt att tala om mäns våld mot kvinnor som ett strukturellt fenomen (Eduards 2002). Det finns alltid motexempel, dubbeltydligheter och enskilda fall som kanske över huvudtaget inte passar in i förhållande till strukturella förklaringar. Utifrån detta är det inte konstigt att socialarbetare ibland vill frikoppla sig från den strukturella nivån och hävda en annan, mer komplex verklighet, som motsäger strukturella synliggöranden av underordnade gruppers utsatthet och överordnade gruppers privilegier och makt. Tydligast blir kanske detta i studien vid enheten som arbetar med våld i nära relationer, där viljan att se och synliggöra komplexiteten i praktiken ibland leder till att personalen helt frikopplar verksamheten från strukturella förståelser av mäns våld mot kvinnor - och då också kommer att osynliggöra kvinnors utsatthet för mäns våld. I studien av missbruksvård blir det på ett annat sätt tydligt hur svår sammankopplingen och den pendlande rörelsen mellan närhet och distans kan vara när området i sig är laddat. Socialarbetarna uttrycker exempelvis många gånger en rädsla och försiktighet i förhållande till att tala om etnicitet men ändå kategoriserar de människor de möter i sitt arbete i förhållande till deras geografiska ursprung, språk och religion. Här finns en påtaglig rädsla bland de intervjuade att göra fel, en rädsla som de ibland hanterar genom att frikoppla sig själva från de strukturella mönster som kan antas bidra till rasialisering (jfr Gunaratnam och Lewis 2001).

Flera av intervjupersonerna i studien såg sin yrkesroll och sitt yrkeskunnande som garanter för objektivitet och neutralitet, garanter för att de inte behandlade människor olika. Vi menar att det är viktigt att lämna tanken om att socialarbetare är neutrala eller objektiva. Socialt arbete är en del av samhälles strukturella maktordningar och vi kan inte frikoppla vare sig det sociala arbetets praktik eller socialarbetaren från dem. Vi är alla handlande subjekt i en specifik samhällsordning som vi också kan utmana och göra motstånd mot, men inte om vi frikopplar oss från den ordning vi är en del av. Tron på objektivitet och neutralitet i förhållande till maktordningar är förrädisk eftersom maktordningar skapas genom neutralisering av makten och av överordnade positioner. Att frikoppla sig 
från strukturella mönster och tro sig vara utanförstående och objektiv innebär stor risk för att snarare vara en del av och upprätthållare av desamma (Burk \& Daniel 1995; Chodorow 1989).

Detta innebär också att det aldrig går att definiera sig som sammankopplande praktiker och sedan vara nöjd med det. Denna typ av deklaration innebär paradoxalt nog också en risk att slappna av och inte anstränga sig. Ahmed (2004) pekar på deklarerandet av medvetenhet och insikt leder till en känsla av godhet. Hon understryker att sådana deklarationer inte givet betyder att vi tar det ansvar vi har för vår privilegierade position och den effekt denna har på underordnade grupper. I ett sammankopplande förhållningssätt menar vi att praktiskt socialt arbete kan nå längre då det skapar möjligheter till en fördjupande förståelse och utveckling. Att arbeta sammankopplande innebär ett ständigt och hårt arbete med att hålla levande förståelsen av hur maktstrukturer påverkar utan att bortse från komplexiteten i det enskilda fallet. I denna process ingår en betraktelse över det egna arbetet och hur man själv är en del i ett upprätthållande av ojämlikhet.
Vi är alla på olika vis del i samhälleliga och sociala maktstruktur och för socialarbetare är detta extra viktigt att vara varse om och ta ansvar för. Ahmed (2004) har lyft fram att detta ansvarstagande kan vara förenat med smärta och liknar det vid en sorgeprocess, där vi i våra överordnande positioner måste möta den smärta som det innebär att hantera och $\mathrm{i}$ vissa fall också ge upp de privilegier som överordningen medför.

Det finns en lång tradition av reflektion som en del av det sociala arbetets praktik (Fook 2002; Schön 2007) och vi menar att det sammankopplande förhållningssättet är ett reflekterande förhållningssätt. Sammankopplingen innebär en reflekterande praktik som är förankrad i en förståelse av att socialt arbete är en del av det samhälle vari det praktiseras, vilket gör maktstrukturer och ojämlikhet till en del av praktikens realitet (Brookfield 2009; Fook 2002; Sakamoto \& Pitner 2005). Den sammankopplande positionen innebär ett ständigt medvetandegörande om vad denna position innebär och hur det går att ta ansvar för den och den är en del av ett ansvar som vi inom socialt arbete bör ta.

\section{Referenser}

Ahmed, Sara (2004) "Declarations of Whiteness: The Non-Performativity of Anti-Racism", Borderlands E-journal, Vol. 3, nr 2.

Anthias Floya \& Nira Yuval-Davis (1996) Racialized boundaries: Race, nation, gender, colour and class and the anti-racist struggle. London, New York: Routledge.

Brookfield, Stephen (2009) "The concept of critical reflection: promises and contradictions", European Journal of Social Work, Vol. 12, nr 3, s. 293-305.

Burck, Charlotte \& Gwyn Daniel (1995) Gender and family therapy. London: Karnac books.

Börjesson, Mats \& Eva Palmblad (2008) Strultjejer, arbetssökande och samarbetsvilliga. Kategoriseringar och samhällsmoral $i$ socialt arbete. Malmö: Liber.

Chodorow, Nancy (1989) Feminism and psycho analytic theory. New Haven and London: Yale University Press.

Laanemets, Mattsson \& Nordling: Frikoppling, sammankoppling och besvärliga... 
Dominelli, Lena (2004) Social work. Theory and Practice for a Changing Profession. Cambridge: Polity Press.

Dominelli, Lena (2002) Anti-oppressive social work. Theory and practice. Basingstoke: Palgrave.

Eduards, Maud (2002) Förbjuden handling: om kvinnors organisering och feministisk teori. Malmö: Liber ekonomi.

Essed, Philomena (1991) Understanding everyday racism: an interdisciplinary theory. Newbury Park: Sage.

Fenstermaker, Sarah \& Candace West (red) (2002) Doing Gender, Doing Difference. Inequality, Power and Institutional Change. New York \& London: Routledge.

Fook, Jan (1993) Radical Casework: a Theory of Practice. St Leonards, NSW: Allen \& Unwin.

Fook, Jan (2002) Social work Critical Theory and Practice. London, Thousand Oaks: Sage.

Fook, Jan \& Fiona Gardner (2007) Practising critical reflection: a resource handbook. Maidenhead: Open University Press.

Gunaratnam, Yasmin \& Gail Lewis (2001) "Racialising emotional labour and emotionalizing racialiced labour: Anger, fear and shame in social welfare", Journal of Social Work practice: Psychoterapeutic Approaches in Health, Welfare and the Community, Vol. 15, nr 2, s. 131-148.

Mattsson, Tina (2005) I viljan att göra det normala: En kritisk studie av genusperspektivet $i$ missbrukarvården. Malmö: Ėgalité.

Mattsson, Tina (2010) Intersektionalitet $i$ socialt arbete. Teori, reflektion och praxis. Malmö: Gleerups.

Mattsson, Tina (2011) Våldets komplexitet och gamla paradigm. Om utmaningar och svairigheter $i$ arbetet med våld i nära relationer. Lund: Meddelandeserien. 2011:5, Socialhögskolan, Lunds universitet.

Mattsson, Tina (2014) Motstånd och neutralisering. Kön, makt och professionalitet $\mathrm{i}$ arbetet med våld i nära relationer. Socialvetenskaplig tidskrift, vol. 21, ss. 150-167.

Mclaughlin, Kenneth (2005) "From ridicule to institutionalization: anti-oppression, the state and social work", Critical Social Policy, Vol. 25, nr 3, s. 283-305.

Morley, Christine (2004) "Critical reflection in social work: A response to globalization", International Journal of Social Welfare, Vol. 13, nr. 4, s. 297-303.

Nordling, Vanna (2011) Att dra gränser - Upplevs etnicitet vara viktigt $i$ arbetet med missbruk och beroende? FoU-rapport 2011:2, Malmö: Malmö stad.

Pease, Bob (2010) Undoing privilege. Unearned advantages in a divided world. London \& New York: Zed Books.

Pitner, Ronald O. \& Izumi Sakamoto (2005) "The Role of Critical Consciousness in Multicultural Practice: Examining How Its Strength Becomes Its Limitation", American Journal of Ortopsychiatry, Vol 75, nr. 4, s. 684-694.

de los Reyes, Paulina \& Diana Mulinari (2005) Intersektionalitet-kritiska reflektioner över (o) jämlikhetens landskap. Malmö: Liber.

de los Reyes, Paulina (2007) "Intersektionella perspektiv på etniska relationer" i Abby Peterson och Mikael Hjerm (red.) Etnicitet: Perspektiv på samhället. Malmö: Gleerups

Robson, Colin (2004) Real World Research, a Resource for Social Scientists and PractionersResearchers. Oxford: Blackwell.

Sakomoto, Izumi \& Ronald O. Pitner (2005) "Use of Critical Consciousness in Anti-Oppressive Social Work Practice: Disentangeling Power Dynamics at Personal and Structural Levels", British Journal of Social Work, Vol. 35, nr 4, s. 435-452.

Schön, Donald (2007) The Reflective Practitioner. How Professionals Think in Action. Aldershot: Ashgate.

Silverman, David (1995) Interpreting Qualitative Data. Methods for Analysing Talk, Text and Interaction. London: Sage Publications.

Stepney, Paul (2005) "Mission impossible? Critical practice in Social Work", British Journal of Social Work, Vol. 36, nr. 8, s. 1289-1307.

Tilly, Charles (2000) Beständig ojämlikhet. Lund: Arkiv förlag.

Young, Iris Marion (2002) Att kasta tjejkast. Texter om feminism och rättvisa. Stockholm: Atlas. 


\section{Summary}

\section{Disconnecting, interconnecting and troublesome power relations in social work}

The aim of this article is to explore the use of categories and categorizations in social work practice and its relation to gender and ethnicity. Based on empirical material from two separate studies, one concerning social work with violence in intimate relations and one on social work with drug users, the authors present two concepts, disconnecting and interconnecting, as a way to understand a tension in how social workers relate to gender and ethnicity. Social workers sometimes disconnect themselves and their practice from the social context, arguing that they are not affected by power structures when meeting the clients. Other times they interconnect themselves with the social context, which makes it possible for them to understand individual cases and power structures in relation to each other. The authors argue that a practice that interconnects the individual case with social structures is painful and difficult but important. The process it requires demands constant reflection upon the social worker's role in relation to power structures in society. 